Review

\title{
The Metabolome and Osteoarthritis: Possible Contributions to Symptoms and Pathology
}

\author{
Jason S. Rockel 1,2,* and Mohit Kapoor 1,2,3,4 \\ 1 Arthritis Program, University Health Network, Toronto, ON M5T 2S8, Canada; \\ mohit.kapoor@uhnresearch.ca \\ 2 Division of Genetics and Development, Krembil Research Institute, University Health Network, \\ Toronto, ON M5T 2S8, Canada \\ 3 Department of Surgery, University of Toronto, Toronto, ON M1C 1A4, Canada \\ 4 Department of Laboratory Medicine and Pathobiology, University of Toronto, \\ Toronto, ON M1C 1A4, Canada \\ * $\quad$ Correspondence: jason.rockel@uhnresearch.ca; Tel.: +1-416-603-5800 (ext. 4797)
}

Received: 30 October 2018; Accepted: 10 December 2018; Published: 13 December 2018

check for updates

\begin{abstract}
Osteoarthritis (OA) is a progressive, deteriorative disease of articular joints. Although traditionally viewed as a local pathology, biomarker exploration has shown that systemic changes can be observed. These include changes to cytokines, microRNAs, and more recently, metabolites. The metabolome is the set of metabolites within a biological sample and includes circulating amino acids, lipids, and sugar moieties. Recent studies suggest that metabolites in the synovial fluid and blood could be used as biomarkers for OA incidence, prognosis, and response to therapy. However, based on clinical, demographic, and anthropometric factors, the local synovial joint and circulating metabolomes may be patient specific, with select subsets of metabolites contributing to OA disease. This review explores the contribution of the local and systemic metabolite changes to OA, and their potential impact on OA symptoms and disease pathogenesis.
\end{abstract}

Keywords: metabolomics; precision medicine; osteoarthritis; local; systemic

\section{Introduction}

Osteoarthritis (OA) is a degenerative joint disease characterized by cartilage degradation, synovitis, subchondral bone thickening, and ectopic bone formation in the form of osteophytes [1]. The etiology of OA is unknown. Current approved therapies only provide symptom relief and are not disease-modifying. Ultimately, patients with OA will need joint replacement therapy once pain, function, and quality of life are no longer satisfactory or adequately controlled. A large proportion of patients who undergo joint replacement surgery continue to feel pain and thus have limited improvement to quality of life and function [2]. Thus, defining patients who are good candidates for surgery is important for providing precision care to each individual.

Traditionally, OA has been viewed as a single disease carrying with it a "one size fits all" approach to treatment. However, a number of different patient phenotypes have been determined based on clinical, demographic, and anthropometric characteristics. Risk factors for OA include age, body mass index (BMI), and sex, among others. Individuals over the age of 50, with a body mass index $>30 \mathrm{~kg} / \mathrm{m}^{2}$, and of the female sex have an increased incidence and risk of OA [3-7]. In addition, individuals with comorbidities such as diabetes have increased incidence and risk of developing OA and may also have accelerated joint pathogenesis as a result [8,9]. Furthermore, some patients present in the clinic with reduced mobility and are pain free, while others can experience severe pain but exhibit limited structural joint disease [10-12]. Based on these multiple patient characteristics, it is likely that there are 
underlying biological differences that can be detected within each patient that would provide insights into tailored care plans.

Considerable effort has been placed into identifying biomarkers of disease incidence and prognosis that could potentially help in identifying new targets for disease modification. The most common biomarkers investigated to date include circulating microRNAs, cytokines, and metabolites. A total of 690 papers can be identified in PubMed up to the end of November 2018 using the search-string "(microRNA OR metabolite OR cytokine) AND osteoarthritis AND biomarker NOT review." Of them, 646 relate to cytokines, 32 pertain to microRNAs, and 20 focus on metabolites, with some articles having keyword overlap between biomarker types. One of the 20 articles focused on metabolite biomarkers in OA is a non-English review article, two are in vitro studies only, one is a study on healthy individuals, and one discusses cleavage products of cartilage in equine synovial fluid and plasma in response to recombinant equine growth hormone injection. The 15 remaining articles are summarized in Table 1. Overall, this indicates that metabolite research in OA is in a relatively early but growing exploratory state, as the majority of articles (11/15) were published between 2015-2018. As metabolites can be used as biomarkers, circulating metabolites or those in urine may be indicative of underlying pathologies. There are a vast number of metabolite changes that have been identified in both blood and synovial fluid of OA patients [13], suggesting that metabolites could influence the various OA pathological features or associated comorbidities in both the local disease environment and in distant organs.

Table 1. Summary of curated publications found in PubMed using the search string "metabolite AND biomarker AND osteoarthritis NOT review."

\begin{tabular}{|c|c|c|c|c|c|c|}
\hline Author & Year & $\begin{array}{c}\text { Fluid/Tissue for } \\
\text { Metabolite Detection }\end{array}$ & Species & Study Groups & $\begin{array}{c}\text { Metabolite } \\
\text { Detection Method }\end{array}$ & Reference \\
\hline Anderson et al. & 2018 & synovial fluid & equine & $\begin{array}{l}\text { septic vs. non-septic joint } \\
\text { pathologies }\end{array}$ & ${ }^{1} \mathrm{H}-\mathrm{NMR}$ & [14] \\
\hline Carlson et al. & 2018 & synovial fluid & human & OA vs. RA vs. healthy & LC-MS & [15] \\
\hline \multirow[t]{2}{*}{ Hinata et al. } & \multirow[t]{2}{*}{2018} & \multirow[t]{2}{*}{ synovial fluid } & rat & $\begin{array}{l}\text { control vs. MIA-induced } \\
\text { OA, sham vs. } \\
\text { meniscectomy-induced OA }\end{array}$ & \multirow[t]{2}{*}{ LC-MS/MS } & \multirow[t]{2}{*}[16]{} \\
\hline & & & human & OA only & & \\
\hline Zhang et al. & 2016 & plasma & human & $\begin{array}{l}\text { primary OA at TKR vs. } \\
\text { healthy control }\end{array}$ & LC-MS/MS & [17] \\
\hline Jin et al. & 2016 & synovial fluid & human & $\begin{array}{l}\text { degenerative vs. traumatic } \\
\text { vs. infectious vs. } \\
\text { inflammatory OA }\end{array}$ & In vivo ${ }^{1} \mathrm{H}-\mathrm{MRS}$ & [18] \\
\hline Loeser et al. & 2016 & urine & human & OA progression vs. stable & ${ }^{1} \mathrm{H}-\mathrm{NMR}$ & [19] \\
\hline Mickiewicz et al. & 2016 & serum & mouse & $\begin{array}{l}\text { sham vs. DMM; wild type } \\
\text { vs. Integrin } 1 \alpha \text {-null; } \\
\text { erlotinib vs. vehicle }\end{array}$ & ${ }^{1} \mathrm{H}-\mathrm{NMR}$ & [20] \\
\hline Hu et al. & 2016 & plasma & human & $\begin{array}{l}\text { primary OA at TKR vs. } \\
\text { healthy control }\end{array}$ & LC-MS/MS & [21] \\
\hline Zhang et al. & 2016 & plasma & human & $\begin{array}{l}\text { primary OA at TKR vs. } \\
\text { healthy control }\end{array}$ & LC-MS/MS & [22] \\
\hline Tufts et al. & 2015 & knee articular cartilage & human & primary OA at TKR & HRMAS-NMR & [23] \\
\hline Zhang et al. & 2015 & plasma, synovial fluid & human & primary OA at TKR & LC-MS/MS & [24] \\
\hline Zhai et al. & 2010 & serum & human & OA vs. healthy control & LC-MS/MS & [25] \\
\hline Davies et al. & 2009 & $\begin{array}{l}\text { synovial fluid, serum, } \\
\text { cartilage }\end{array}$ & human & $\begin{array}{l}\text { active OA, inactive OA, } \\
\text { post-mortem controls }\end{array}$ & HPLC & [26] \\
\hline Lamers et al. & 2005 & urine & human & $\begin{array}{l}\text { radiographic OA vs. } \\
\text { non-OA controls }\end{array}$ & ${ }^{1} \mathrm{H}-\mathrm{NMR}$ & [27] \\
\hline Basu et al. & 2001 & serum, synovial fluid & human & $\begin{array}{l}\text { control (serum only) vs. OA } \\
\text { vs. RA vs. ReA vs. PsA }\end{array}$ & radioimmunoassay & [28] \\
\hline
\end{tabular}

${ }^{1} \mathrm{H}-\mathrm{MRS}$; proton magnetic resonance spectroscopy, ${ }^{1} \mathrm{H}-\mathrm{NMR}$, proton nuclear magnetic imaging; DMM, destabilization of the medial meniscus; HPLC, high performance liquid chromatography; HRMAS, high-resolution magnetic angle spinning; LC, liquid chromatography; MIA; mono-iodoacetate; MS, mass spectrometry; OA, osteoarthritis; PsA, psoriatic arthritis; RA, rheumatoid arthritis; ReA, reactive arthritis; TKR, total knee replacement. 
This review aims to summarize the changes to the metabolome, determined both locally as well as systemically, in relation to $\mathrm{OA}$ and associated pathologies. In addition, this review will explore the various OA phenotypes that have been identified and how demographic, anthropometric, and clinical variables can affect not only OA disease incidence and prognosis, but how these variables can modify the metabolome and contribute to symptoms and biological pathologies associated with OA.

\section{The Local and Systemic Metabolomes of Osteoarthritis}

In the local environment, the joint is bathed in synovial fluid, which contains factors that accumulate through release from local tissues and from the systemic circulation through blood vessels found in the synovium. Changes to the nutrient levels in the synovial fluid, including various metabolites, may directly contribute to inflammatory responses in OA leading to joint pathologies [29]. Metabolomic analysis of human synovial fluid has uncovered a variety of metabolites altered in OA compared to healthy controls. These include concentration-dependent changes to select lipid, sugar, and amino acid derivatives, which are associated with OA diagnosis or grade [30-32]. In synovial fluid, a variety of metabolites including amino acids, sugars, and metabolites involved in energy production, measured by proton nuclear magnetic resonance $\left({ }^{1} \mathrm{H}-\mathrm{NMR}\right)$, could differentiate horses with septic vs. non-septic joint pathologies [14]. Similarly, in an ovine model of early OA, metabolomic analysis of synovial fluid uncovered six significantly altered metabolites, namely isobutyrate, glucose, uridine, serine, asparagine, and hydroxyproline, which could be used as early OA biomarkers [33]. Two contradictory studies have indicated that human rheumatoid arthritis (RA) and OA are indistinguishable [34] or dipartite [35], based on ${ }^{1} \mathrm{H}-\mathrm{NMR}$ spectra. However, alternate metabolite detection platforms confirm differences in metabolites from OA and RA synovial fluid [36], suggesting that the OA metabolome could be used for differential diagnosis. Furthermore, patients with low-grade versus high-grade radiographic OA severity (Kellgren Lawrence (KL)1/2 versus KL3/4 [37]) can be discriminated based on a signature of 28 metabolites in synovial fluid as determined by gas chromatography/time of flight mass spectrometry (GC/TOF-MS) [38]. This suggests that the methods of metabolite detection as well as cohorts used are likely to impact biomarker discovery.

Although OA is primarily considered a localized disease, it has become abundantly clear that systemic effects could contribute to OA symptoms and pathology [39]. A subset of eight metabolites that include three branched chain amino acids (BCAAs), three phospholipids, glycine, and creatinine are highly correlated by concentration in the synovial fluid and plasma of OA patients [24], suggesting some degree of potential interaction between the circulating metabolome and the local joint metabolome. Recent metabolomic studies have uncovered a number of metabolites that are dysregulated in the systemic circulation. For instance, in one of the first serum-based metabolomics study of OA in humans, the ratios of individual branched chain amino acids or total BCAAs to histidine concentrations were determined to be significantly different between OA patients and healthy controls $[17,25]$, and subsequently total BCAAs:histidine was found to be predictive of individuals with OA [17]. Further studies show changes to a variety of different lipid species including phosphatidylcholines (PCs), lysophosphatidylcholines (lysoPCs), sphingolipids, and select amino acids including arginine $[17,22]$. A study of a cohort from Newfoundland, Canada, found that the ratio of total lysoPCs to PCs is predictive of advanced OA leading to total knee replacement in a 10-year follow-up [17]. Sustained changes to the plasma metabolome, particularly selected lysoPC and PC analogues, were also identified in mice fed a high-fat diet compared to a lean or normal chow-fed diet, correlating with acceleration of surgically-induced OA [40]. Furthermore, in overweight and obese individuals, urinary metabolomics was able to distinguish individuals whose OA progressed versus those with stable disease over a span of 18 months [19]. In rat models of OA, changes to amino acid metabolism are also observed in urine [41]. Again in rats, a longitudinal metabolomic analysis of plasma showed that there are significant and time-dependent changes in products of lysine metabolism after surgical induction of OA [42]. This further suggests that amino acid metabolism 
may contribute to OA pathology or that select amino acid levels could be used as biomarkers of OA incidence and progression.

As there are a large number of metabolic changes that occur systemically in response to OA, it is not surprising that some of these changes also correlate to functional changes in other organs. For instance, select medium- and long-chain acylcarnitine moieties are systemically reduced in patients with OA compared to healthy controls, possibly a result of increased energy demands and/or reduced $\beta$-oxidation from impaired carnitine palmitoyltranferase enzyme function, the rate-limiting enzyme for long-chain $\beta$-oxidation. These changes also correlate to arterial stiffness, a pathology associated with cardiovascular disease [43] and a comorbidity whose risk is increased in individuals with OA [44-49]. OA also increases the risk of developing type 2 diabetes [50], a metabolic disorder on its own. Interestingly, individuals with OA and comorbidities such as diabetes, cardiovascular disease, and obesity, or who have high consumption of fats, have accelerated cartilage degeneration [8,51,52]. In fact, diabetes is an independent risk factor for OA incidence and surgery [53,54]. There is an abundance of information linking diabetes to an increased risk of cardiovascular disease [55]; however, to our knowledge, there is no published literature that has explored whether cardiovascular disease increases the risk of incident OA. Overall, there is a link between and across these diseases that could be explained, in part, by changes in lifestyle associated with each disease. However, underlying biochemical changes in the circulating metabolome are also likely to be altered and could profoundly affect both incidence and progression of each disease. Understanding metabolome links between co-morbidities may help to understand underlying pathologies and provide novel therapeutic avenues to treat multiple diseases concurrently.

\section{Osteoarthritis Phenotypes and Impact on Metabolome}

$\mathrm{OA}$ is a heterogeneous disease and incorporates a number of disease phenotypes with similar pathologies. From independent cohort studies, common clinical and anthropometric variables stand out as being key to defining the risk of $\mathrm{OA}$ incidence and potential clinical outcomes. These include age, sex, and BMI. Each of these variables can also carry its own metabolic "signature," which could complicate subsequent analysis. For instance, age, when adjusted for BMI, has a specific serum metabolite signature that differs in males and females [56], confounding how metabolites may be identified in large population-based studies. In addition, a study comparing plasma from individuals with obesity to those with metabolic syndrome identified a signature of metabolites that could differentiate these individuals, which included branched chain amino acids (BCAAs) such as leucine and isoleucine [57]. This suggests that BCAAs from individuals with metabolic syndrome could contribute to OA symptoms or pathologies; however, no such studies, to our knowledge, have investigated this link. Our recent research has determined that stratification of cohorts based on sex and $\mathrm{BMI}$ is necessary to uncover the differential plasma metabolite signatures between healthy control and OA patients at TKR, which are heavily biased towards males [58]. This study also identified that select metabolite signatures composed of individual lysoPC and PC analogues are better at predicting OA incidence compared to total aggregates of lysoPCs and PC analogue types. Furthermore, metabolites in plasma alone can classify different OA phenotypes into two major subgroups without any confounders including age, sex, or BMI [59] suggesting that OA disease may have multiple metabolite signatures that could prove useful in precision medicine applications.

Clinical phenotypes have also been identified which include, but are not limited to, pain sensitization or neuropathic pain, muscle strength, BMI, and level of depression [10-12]. How each of these phenotypes could influence the metabolome is described below and articles related to each phenotype are summarized in Table 2. 
Table 2. Selected publications indicating metabolite changes in phenotypes related to osteoarthritis.

\begin{tabular}{|c|c|c|c|c|c|c|c|}
\hline Phenotype & Author & Year & $\begin{array}{c}\text { Fluid/Tissue for } \\
\text { Metabolite Detection }\end{array}$ & Species & Study Groups & $\begin{array}{l}\text { Metabolite Detection } \\
\text { Method }\end{array}$ & Reference \\
\hline \multirow{3}{*}{ Pain } & Finco et al. & 2016 & urine & human & nociceptive pain vs. neuropathic pain vs. pain free & ${ }^{1} \mathrm{H}-\mathrm{NMR}$ & [60] \\
\hline & Hadrevi et al. & 2015 & serum & human & women with chronic neck pain, chronic widespread pain vs. healthy control & GS-MS & [61] \\
\hline & Um et al. & 2009 & urine & rat & celecoxib vs. indomethacin vs. ibuprofen vs. vehicle; gastric damaged vs. undamaged & ${ }^{1} \mathrm{H}-\mathrm{NMR}$ & [62] \\
\hline \multirow{7}{*}{$\begin{array}{l}\text { Muscle } \\
\text { Strength }\end{array}$} & Srivastava et al. & 2018 & skeletal muscle & human & $\begin{array}{l}\text { Duchenne muscular dystrophy vs. Becker muscular dystrophy vs. facioscapulohumeral dystrophy vs. limb girdle muscular } \\
\text { dystrophy vs. healthy control }\end{array}$ & ${ }^{1} \mathrm{H}-\mathrm{NMR}$ & [63] \\
\hline & Cieslarova et al. & 2017 & plasma & human & ALS vs. healthy control & CE-MS/MS & [64] \\
\hline & Patin et al. & 2017 & $\begin{array}{c}\text { Muscle and brain } \\
\text { (mouse only), plasma }\end{array}$ & $\begin{array}{c}\text { human and } \\
\text { mouse }\end{array}$ & mSOD ${ }^{*} \mathrm{G} 39 \mathrm{~A}$-transgenic mice vs. WT mice; ALS vs. healthy control & ${ }^{1} \mathrm{H}-\mathrm{NMR}$ & [65] \\
\hline & Files et al. & 2016 & skeletal muscle & mouse & adult vs. old; sham vs. acute lung injury-induced muscle wasting & GS-MS & [66] \\
\hline & Moaddel et al. & 2016 & plasma & human & low vs. high muscle quality in older men and women & LC-MS/MS & [67] \\
\hline & $\begin{array}{l}\text { Wuolikainen et } \\
\text { al. }\end{array}$ & 2016 & CSF and Plasma & human & ALS and Parkinson's disease vs. healthy control & GC-MS; LC-MS & [68] \\
\hline & Sengupta et al. & 2014 & serum & human & myasthenia gravis prednisone treated vs. baseline & UPLC-ESI-QTOF-MS & [69] \\
\hline \multirow{21}{*}{ Obesity } & Cirulli et al. & 2018 & serum, plasma & human & metabolically obese vs. metabolically overweight vs. metabolically healthy & LC-MS/MS & [70] \\
\hline & Libert et al. & 2018 & plasma & human & $\begin{array}{l}\text { lean metabolically well vs. obese metabolically well vs. obese metabolically unwell vs. obese metabolically unwell with } \\
\text { type II diabetes }\end{array}$ & LC-MS/MS & [71] \\
\hline & Moore et al. & 2018 & serum & human & correlation of BMI and breast cancer risk to circulating metabolites in postmenopausal women & LC-MS/MS & [72] \\
\hline & Munlandy et al. & 2018 & plasma & human & $\begin{array}{l}\text { correlation of metabolites to cardiometabolic risk factors (including BMI, \% body fat, visceral fat, subcutaneous fat) in } \\
\text { monozygotic twins }\end{array}$ & LC-MS/MS & [73] \\
\hline & Baek et al. & 2017 & plasma & human & low vs. high visceral fat area in a Korean cohort & LC-MS & [74] \\
\hline & Carayol et al. & 2017 & serum, plasma & human & correlation of BMI to circulating metabolites & LC-MS/MS & [75] \\
\hline & Okekunle et al. & 2017 & serum & human & obese vs. type II diabetes vs. metabolic syndrome vs. healthy control & UPLC-TQ/MS & [76] \\
\hline & Zhong et al. & 2017 & plasma & human & obese vs. metabolic syndrome & LC-MS/MS & [57] \\
\hline & Boglet al. & 2016 & serum & human & correlation of phenotypic and obesity-related measures to metabolite levels in dizygotic and monozygotic twins & ${ }^{1} \mathrm{H}-\mathrm{NMR}$ & [77] \\
\hline & Dugas et al. & 2016 & serum & human & normal vs. obese; black women from U.S. vs. South Africa vs. Ghana & GC-TOF/MS & [78] \\
\hline & Gao et al. & 2016 & serum & human & metabolically unhealthy centrally obese vs. metabolically healthy peripherally obese & LC-MS/MS & [79] \\
\hline & Ho et al. & 2016 & plasma & human & correlation of BMI, waist circumference, and other metabolic traits to circulating metabolites & LC-MS/MS & [80] \\
\hline & Tulipani et al. & 2016 & serum & human & BMI-discordant non-diabetic vs. pre-diabetic monozygotic twins & $\begin{array}{l}\text { LC-MS/MS; } \\
\text { FIA-MS/MS; } \\
\text { ESI-MS/MS }\end{array}$ & [81] \\
\hline & Zhao et al. & 2016 & plasma & human & correlation of metabolites to BMI and weight gain in Mexican American women & LC-MS/MS & [82] \\
\hline & Boulet et al. & 2015 & plasma & human & lean vs. overweight vs. obese women & $\begin{array}{l}\text { ESI-LC-MS/MS, } \\
\text { ESI-MS/MS }\end{array}$ & [83] \\
\hline & Chen et al. & 2015 & serum & human & metabolic healthy obese vs. metabolic unhealthy obese & LC-MS; GC-MS & [84] \\
\hline & Gralka et al. & 2015 & serum & human & obese vs. normal weight & ${ }^{1} \mathrm{H}-\mathrm{NMR}$ & [85] \\
\hline & Floegel et al. & 2014 & serum & human & $\begin{array}{l}\text { correlation of metabolite networks to different dietary, activity and anthropometric exposures (including BMI and waist } \\
\text { circumference) }\end{array}$ & LC-MS/MS & [86] \\
\hline & Moore et al. & 2014 & serum, plasma & human & correlation of metabolite levels to BMI & $\begin{array}{l}\text { LC-MS/MS; } \\
\text { GC-MS/MS }\end{array}$ & [87] \\
\hline & Martin et al. & 2013 & plasma, urine & human & correlation of metabolites to body fat distribution in obese women & LC-MS/MS & [88] \\
\hline & Batch et al. & 2013 & plasma & human & lean vs. overweight vs. obese & $\begin{array}{l}\text { LC-MS/MS; } \\
\text { ESI-MS/MS }\end{array}$ & [89] \\
\hline
\end{tabular}


Table 2. Cont.

\begin{tabular}{|c|c|c|c|c|c|c|c|}
\hline Phenotype & Author & Year & $\begin{array}{c}\text { Fluid/Tissue for } \\
\text { Metabolite Detection }\end{array}$ & Species & Study Groups & $\begin{array}{l}\text { Metabolite Detection } \\
\text { Method }\end{array}$ & Reference \\
\hline \multirow{12}{*}{ Depression } & Ali-Sisto et al. & 2018 & serum & human & major depressive disorder vs. non-depressed controls, remitted vs. non-remitted patients with major depressive disorder & LC-MS & [90] \\
\hline & Kawamura et al. & 2018 & plasma & human & major depressive disorder vs. mentally healthy controls & CE-TOF/MS & [91] \\
\hline & Moaddel et al. & 2018 & plasma & human & major depressive disorder vs. healthy controls, ketamine vs. placebo & LC-MS/MS & [92] \\
\hline & Zheng et al. & 2017 & plasma & human & major depressive disorder vs. healthy controls & ${ }^{1} \mathrm{H}$-NMR & [93] \\
\hline & Ali-Sisto et al. & 2016 & serum & human & major depressive disorder vs. non-depressed controls & LC-MS/MS & [94] \\
\hline & Liu et al. & 2016 & plasma & human & healthy controls vs. major depressive disorder, melancholic depressed, anxious depressed & LC-MS/MS, GC-MS & [95] \\
\hline & Rotroff et al. & 2016 & plasma & human & baseline vs. post-treatment of patients with major depressive disorder treated with placebo, ketamine, or esketamine & $\begin{array}{l}\text { LC-MS/MS, } \\
\text { GC-TOF/MS }\end{array}$ & [96] \\
\hline & Setoyama et al. & 2016 & plasma & human & $\begin{array}{l}\text { correlation of metabolites to depression severity in patients with psychiatric disorders, drug-free major depressive disorder, } \\
\text { or bipolar disorders; medicated major depressive disorder and bipolar disorders }\end{array}$ & LC-MS & [97] \\
\hline & Zheng et al. & 2016 & urine & human & major depressive disorder vs. healthy controls, women vs. men & ${ }^{1} \mathrm{H}-\mathrm{NMR}, \mathrm{GC}-\mathrm{MS}$ & [98] \\
\hline & Woo et al. & 2015 & plasma & human & $\begin{array}{l}\text { healthy controls vs. major depressive disorder patients baseline vs. major depressive disorder patients 6-weeks post SSRI } \\
\text { treatment }\end{array}$ & LC-MS/MS & [99] \\
\hline & Zheng et al. & 2012 & plasma & human & drug-naïve first episode depression vs. healthy controls & ${ }^{1} \mathrm{H}-\mathrm{NMR}$ & [100] \\
\hline & Paige et al. & 2007 & plasma & human & remitted depressed vs. non-remitted depressed vs. non-depressed older adults & GC-MS & [101] \\
\hline
\end{tabular}

${ }^{1} \mathrm{H}-\mathrm{NMR}$, proton nuclear magnetic imaging; ALS, amyotrophic lateral sclerosis; BMI, body mass index; CE, capillary electrophoresis; CSF, cerebrospinal fluid, ESI, electrospray ionization;

FIA, flow injection analysis; GC, gas chromatography; LC, liquid chromatography; MS, mass spectrometry; QTOF, quadrupole time of flight; SSRI, selective serotonin reuptake inhibitor;

TOF, time of flight; UPLC, ultra-performance liquid chromatography; WT, wild-type. 


\subsection{Pain}

OA pain is typically classified into neuropathic (nerve damage associated) or nociceptive (inflammatory or tissue damage associated) [102]. A pilot study of pain indicated that neuropathic pain, nociceptive pain, and pain-free individuals can be differentiated using global metabolomic profiling of urine; although, a preliminary signature for each classification was not provided [60]. Furthermore, in a study of women with widespread pain compared to localized pain, distinct differences in circulating serum metabolites can be identified compared to control subjects [61]. Various metabolites can directly influence the perception of pain. Endocannabinoids are endogenously produced lipid-derived compounds that act as analgesics [103]. OA patients have higher levels of select endocannabinoids in the synovial fluid compared to normal individuals [104]. Thus, endocannabinoid production could be beneficial for individuals with OA to reduce pain symptoms. However, there may also be detrimental effects of increasing endocannabinoid production. Endocannabinoids use PCs as donors for their biosynthesis, resulting in the production of lysoPCs [105]. LysoPCs could promote joint pathology and ultimately pain due to metabolism to lysophosphatidic acid (LPA), an inflammatory and pain-producing signal (described in the PC-lysoPC-LPA pathway below). This could be an interesting therapeutic target for both OA symptoms and joint pathologies. Drugs used to treat pain also have effects on the metabolome. Urine analysis of rats treated with non-steroidal anti-inflammatory drugs (NSAIDs) showed altered components of the metabolome, as determined using ${ }^{1} \mathrm{H}-\mathrm{NMR}$ [62]. As NSAIDs are readily prescribed for the treatment of pain in OA, it will be necessary to evaluate how specific metabolic pathways may be affected systemically to determine potential positive and negative outcomes to NSAID use for OA.

\subsection{Muscle Strength}

Weak muscle strength is a risk factor for development and progression of knee OA [106,107]. In a mouse model of muscle wasting, gastrocnemius muscle showed changes in linoleic acid, lactate, serine, alanine, and long-chain acyl-carnitines, as measured by gas chromatography-mass spectrometry, compared to controls [66]. Several muscular dystrophy disorders also carry a variety of metabolite differences in muscle tissue, as measured using ${ }^{1} \mathrm{H}-\mathrm{NMR}$, including BCAAs, glutamine/glutamate, histidine, acetate, propionate, fumarate, and tyrosine [63]. With regard to systemic metabolomics, a study on serum from patients with myasthenia gravis, an autoimmune neuromuscular disease resulting in muscle weakness, showed alterations of metabolite levels of a variety of glycerophospholipids with prednisone treatment [69]. In addition, there is an abundance of studies investigating circulating metabolite changes and their contributions to amyotrophic lateral sclerosis (ALS), which results in muscle weakness and paralysis in response to motor neuron degeneration. For instance, cystine and glutamic acid levels are elevated in the serum of ALS patients compared to normal subjects [64], whereas 35 metabolites in plasma could differentiate between ALS patients and healthy controls [68]. Furthermore, metabolomics analysis of blood, muscle, and brain of mice and plasma of humans suggests that arginine, proline, lysine, tryptophan, glutamate and BCAA metabolism are altered in ALS patients across tissues/fluids and species studied [65]. Additional ALS metabolomics studies are well-reviewed elsewhere [108,109]. However, muscle strength has not been well characterized with regard to its contribution to circulating plasma metabolite levels in human subjects without confounding comorbidities. In a study of a small cohort of individuals, the force exerted per muscle area by the quadriceps had a direct relationship with the systemic metabolome. Differences in PCs, lysoPCs, and various amino acids, including increased levels of leucine and isoleucine were found in weak muscle vs. control individuals [67], suggesting a possible contribution of phospholipids and BCAAs to the metabolome of OA patients with a weak muscle phenotype. Collectively, these studies suggest that there could be a link between weak muscle strength and OA incidence and progression; however, further research is needed to define metabolites from a weak muscle phenotype directly contributing to OA. 


\subsection{Obesity}

There are numerous studies indicating differences in metabolite levels that are associated with BMI. For instance, in a study of normal, overweight, and obese women, BCAA concentrations in addition to kynurenine/tryptophan ratio were significantly increased in obese compared to lean and overweight individuals [83]. In a separate study, obese individuals had 10 increased and 4 decreased amino acids in circulating serum compared to healthy controls, which included BCAAs [76]. Visceral fat likely plays a role in detected metabolites correlating with BMI, as evidenced from studies of Korean individuals and women with varying levels of visceral fat $[74,88]$. Individuals with central obesity can also be distinguished using metabolite signatures from peripheral obesity or normal weight individuals based on serum increases in valine, isoleucine, leucine, alpha-aminoadipic acid, and C3 acylcarnitine [79]. Waist circumference in populations of dizygotic and monozygotic twins also correlates with a unique signature of serum metabolites, including valine, leucine and isoleucine [77]. Not surprisingly, BMI-based and waist circumference-based metabolite networks derived from serum metabolomic measurements are strongly correlated [86], suggesting that waist circumference and BMI could be interchangeable measures when it comes to circulating metabolites. Metabolomic analysis of plasma in Mexican American women indicates that there are seven metabolites significantly associated with BMI and six with further weight gain at a five-year follow-up [82]. In a study using three separate cohorts in the U.S. and China, a signature of 37 metabolites made up primarily of amino acids and lipids, including a variety of BCAAs, were found to be altered systemically with BMI [87]. In another study, three lysoPC analogues were found to be inversely correlated with BMI [81]. In larger cohort studies, alterations in multiple metabolites from plasma and serum were found to be associated with BMI, including BCAAs, such as valine, leucine, and isoleucine, and various lipids including lysoPC, PC, and sphingomyelins moieties [72,75,80]. Severely obese individuals also show a metabolic signature in serum, which contains a number of aromatic and branched-chain amino acids that are upregulated compared to non-obese controls [85]. Obese, metabolically-unwell individuals who have characteristics of hypertension, hyperglycemia, and dyslipidemia, showed more metabolite changes than obese, metabolically-well individuals, as compared to lean controls. In addition, obese metabolically-disparate individuals can be differentiated based on select serum metabolite levels [71,84]. Metabolic wellness, independent of BMI, can be measured by levels of BCAAs and groups of other metabolites including select short and medium chain acylcarnitines [89]. Consistently, a signature of metabolites can also differentiate obesity from metabolic syndrome [57]. Although select abnormal metabolome signatures can be attributed to obese individuals, there are cases where these signatures can also be found in normal weight subjects while some normal weight subjects can have an obese metabolome signature. This suggests a degree of heterogeneity of metabolomes of both healthy weight and obese individuals [70]. Even monozygotic twins have different plasma metabolomes likely due to environment, lifestyle, and diet, which are independent of genetics and linked to metabolic risk phenotypes [73]. The effect of environment is further supported by a study of black women from the U.S., South Africa, and Ghana, which indicates a common signature of amino acids, consisting in part of BCAAs, is present between populations while site specific obesity-related metabolites are also detected [78]. Overall, these studies suggest that increasing BMI changes the metabolome to favor metabolite patterns commonly associated with OA, possibly contributing to OA symptoms and pathogenesis. However, BMI alone may not be a minimal criterion, and metabolite levels may independently influence OA disease progression. Of particular interest, increased BCAA levels associated with many obesity-related metabolic profiles may play a vital role both systemically and locally during OA pathogenesis, as discussed below.

\subsection{Depression}

Depression contributes to the differential severity of symptoms reported by patients with OA, including pain and physical function [110]. Metabolomic analysis of individuals with depression show alterations in the serum or plasma levels of select sugars, amino acid, lipids, and purine 
metabolites, among others, compared to control individuals [91,93-95,97,99-101]. Sex is also a major contributing factor to changes found in the metabolome of depressive individuals. In urine, there are large differences in the metabolome between men and women with depression, with men having a larger number of metabolites showing significant changes [98]. Consequently, therapies used to treat depression can also have an impact on metabolites and change the landscape of the metabolome. For instance, selective serotonin reuptake inhibitors (SSRIs), as well as ketamine, can treat severe depression and change a variety of circulating amino acids in blood plasma, including increasing arginine in drug responders [92,96,99]. Interestingly, like in OA, arginine is reduced in individuals with depression [90]. Thus, depression may exacerbate OA symptoms or pathologies, in part, through changes in arginine metabolism, as described below. In addition, drugs known to treat depression may be valuable in OA therapy, consistent with pre-clinical animal studies showing that local injection of the SSRI fluoxetine attenuates OA progression [111]. Whether this phenomenon could be partially due to local changes to the OA metabolome requires further study.

\section{Metabolites and Pathways Likely Contributing to Osteoarthritis}

Based on clinical, anthropometric, and demographic parameters, it is clear that common metabolic pathways are altered in $\mathrm{OA}$ and likely contribute to local and systemic disease pathologies. These include (but are likely not limited to) arginine, lysoPC, and BCAA metabolism. A diagrammatic overview of the molecules, major enzymes, and outcomes are found in Figure 1.

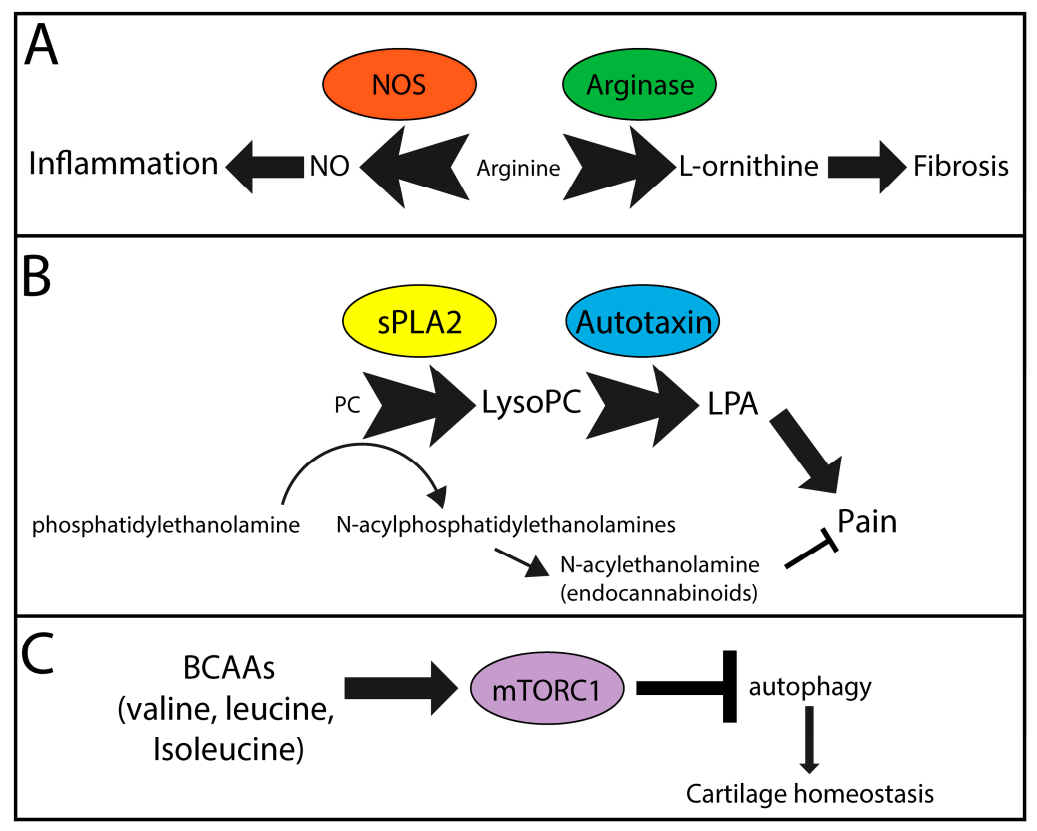

Figure 1. Metabolic pathways likely contributing to symptoms and pathology in OA. (A) Nitric oxide synthase (NOS) and arginase compete for arginine, which is reduced in the OA metabolome, to generate nitric oxide (NO) and L-orninithe, contributors to inflammation and fibrosis, respectively. (B) Secreted phospholipase A2 (sPLA2) catalyzes the conversion of phosphatidylcholine (PC) analogues to lysoPC analogues. Subsequent metabolism of lysoPCs via autotaxin generates lysophosphatidic acid (LPA), a signaling molecule known to promote pain. Furthermore, generation of endocannabinoids from phosphatidylethanolamines requires PC analogues, also contributing to lysoPC production. Resulting endocannabinoids function to reduce pain. (C) Branched chain amino acids (BCAAs) induce mammalian target of rapamycin complex 1 (mTORC1), which inhibits intracellular autophagy, a mechanism that protects cartilage homeostasis. Overall this leads to cartilage destruction and increased chondrocyte cell death. (A-C) Text size indicates concentration/activity of individual factors. Arrow/block arrow thickness indicates the likely relative contribution of each pathway in OA symptom and pathology development. 


\subsection{PC-lysoPC-LPA}

PCs are converted into lysoPCs by phospholipase A1 or A2 (PLA1/2) [112]. In OA, there is an increase in the expression of secreted PLA2 (sPLA2) in cells of the synovium [113], whereas human chondrocytes constitutively express sPLA2 [114]. Subsequently, autotaxin is the main enzyme that converts lysoPCs to LPA [115,116], a major contributor to pain and inflammation [117-123]. Increased circulating and synovial fluid levels of autotaxin have been detected in patients with OA compared to normal controls [124]. In rats, injection of LPA into the knee joint results in nerve demyelination and increased pain [125]. In a rat model of OA pain, an autotaxin inhibitor was able to attenuate pain sensitization, suggesting the activity of autotaxin and lysoPC production likely contribute to symptoms of OA [126]. Leptin is a hormone that is increased in the serum and synovial fluid of OA patients and positively correlates with BMI, increased cartilage degeneration, and female sex [127-130]. We showed that leptin increases the release of lysoPC from chondrocytes, coinciding with increased expression of autotaxin [40]. Furthermore, our in vitro data using human OA chondrocytes showed that an autotaxin inhibitor attenuated the leptin-induced chondrocyte expression of matrix metalloproteinase 13 , the major cartilage extracellular matrix catabolic enzyme. Thus, autotaxin may be an OA disease and symptom-modifying target due, in part, to its ability to modify the local and systemic metabolome; however, further investigation in appropriate in vivo models is necessary to verify autotoxin inhibitors as potential multimodal therapeutics for OA. Similarly, clinical phenotypes such as obesity, muscle strength, and pain may all be influenced by changes to lysoPCs, contributing to OA pathogenesis, as described above.

\subsection{BCAA-mTOR}

Increases in the levels of valine, leucine, and isoleucine in the circulating plasma suggest that there may be dysregulated metabolism in OA patients. BCAAs are normally converted into acetyl-CoA and succinlyl-CoA, vital metabolites for energy production in the tricarboxycylic acid cycle. Increases in BCAAs are known to influence autophagy [131], specifically through the activation of mammalian target of rapamycin complex 1 (mTORC1) [132]. For instance, BCAAs increase migration of mononuclear cells via activation of mTORC1 [133], suggesting the potential for increased inflammation, an underlying pathology of OA [134]. In mouse models of OA, activation of mTOR promotes cartilage degeneration, and treatment with rapamycin attenuates cartilage degeneration when administered intra-articularly $[135,136]$. Altered levels of BCAAs may also contribute to insulin sensitivity and the risk of developing type II diabetes [137], as observed in OA patients. Thus, evidence suggests that an imbalance of BCAAs could lead to reduced autophagy, thereby changing cell survival and overall tissue homeostasis both systemically and in the joint, contributing to overall OA pathophysiology. Increases in BCAAs could also be contributing to or result from other clinical variables associated with phenotypes of $\mathrm{OA}$, including weak muscle strength and obesity, as described above.

\subsection{Arginine-NO/L-ornithine}

There are competing metabolic pathways which utilize arginine as a substrate. Nitric oxide synthase (NOS) catalyzes the production of citrulline and nitric oxide (NO) from L-arginine [138]. Arginase produces urea and L-ornithine, which, through further metabolism, contributes to collagen synthesis and cell proliferation, factors involved in fibrosis [139,140], a pathology associated with OA. Interestingly, ornithine is increased and the ratio of arginine to ornithine is decreased in patients with OA compared to controls [22]. M2-like macrophages, typically thought of as anti-inflammatory, express arginase and promote aortic fibrosis in a mouse model of hypertension [141] and skeletal muscle fibrosis in aged mice [142]. This is in contrast to other studies that suggest that arginase-expressing macrophages are necessary to prevent Th-2-mediated fibrosis and inflammation in the liver of a schistosoma-induced fibrosis model [143]. This anti-inflammatory and anti-fibrotic role may be Th2-selective [144]. As OA is primarily Th1-mediated [145-147], inflammation and NO production 
would likely contribute to disease progression [148]. However, inducible NOS (iNOS) knockout mice have accelerated surgically-induced OA, suggesting that iNOS activity is protective against pathogenesis of surgically-induced OA [149]. Overall, based on the link of OA to cardiovascular disease, there may be a systemic push towards fibrosis while the local joint environment may have both pro-inflammatory, NO-mediated destruction, and fibrosis via arginine catabolism. As arginine is also decreased in depression, this would suggest that depression may be a consequence of changes in the OA metabolome or could exacerbate OA pathologies including fibrosis, inflammation, and pain.

\section{Conclusions}

Based on changes in the circulating metabolome, it is apparent that OA can result from and contribute to the overall systemic health of an individual. Multiple variables can contribute to changes in the metabolome in OA, including age, sex, BMI, and various co-morbidities including diabetes, depression, and cardiovascular disease. Thus, OA can be considered a complex, system-wide disease with heterogeneous etiologies where multiple variables, including the metabolome, should be weighed when caring for patients and treating the disease. Furthermore, therapies used to treat comorbidities such as depression, diabetes, and cardiovascular disease, should also be evaluated for impact in the local joint environment to determine whether local, in addition to systemic therapy, could alleviate OA pathologies and symptoms. In particular, the effects of these therapies on the local and systemic metabolome should be studied to define how these drugs influence the metabolites that cells and tissues respond to, and what types of symptom-modifying or disease-modifying responses could be expected. Further studies should concentrate on metabolic pathways known to be altered in OA including PC-lysoPC-LPA, BCAA-mTOR, and arginine-NO/L-ornithine pathways and their links to other comorbidities with common metabolite profile changes including diabetes, depression, and cardiovascular disease.

Funding: This study is supported from a grant to MK by the Campaign to Cure Arthritis via the Toronto General and Western Foundation, University Health Network, Toronto.

Acknowledgments: We thank S.A. Ali and A. Ratneswaran for their insightful comments and edits.

Conflicts of Interest: The authors declare no conflict of interest.

\section{References}

1. Martel-Pelletier, J.; Barr, A.J.; Cicuttini, F.M.; Conaghan, P.G.; Cooper, C.; Goldring, M.B.; Goldring, S.R.; Jones, G.; Teichtahl, A.J.; Pelletier, J.P. Osteoarthritis. Nat. Rev. Dis. Primers 2016, 2, 16072. [CrossRef] [PubMed]

2. Beswick, A.D.; Wylde, V.; Gooberman-Hill, R.; Blom, A.; Dieppe, P. What proportion of patients report long-term pain after total hip or knee replacement for osteoarthritis? A systematic review of prospective studies in unselected patients. BMJ Open 2012, 2, e000435. [CrossRef] [PubMed]

3. Maradit Kremers, H.; Larson, D.R.; Crowson, C.S.; Kremers, W.K.; Washington, R.E.; Steiner, C.A.; Jiranek, W.A.; Berry, D.J. Prevalence of Total Hip and Knee Replacement in the United States. J. Bone Joint Surg. Am. 2015, 97, 1386-1397. [CrossRef] [PubMed]

4. Singh, J.A.; Lewallen, D.G. Time trends in the characteristics of patients undergoing primary total knee arthroplasty. Arthrit. Care Res. 2014, 66, 897-906. [CrossRef] [PubMed]

5. Oliveria, S.A.; Felson, D.T.; Reed, J.I.; Cirillo, P.A.; Walker, A.M. Incidence of symptomatic hand, hip, and knee osteoarthritis among patients in a health maintenance organization. Arthritis Rheum. 1995, 38, 1134-1141. [CrossRef] [PubMed]

6. Apold, H.; Meyer, H.E.; Nordsletten, L.; Furnes, O.; Baste, V.; Flugsrud, G.B. Risk factors for knee replacement due to primary osteoarthritis, a population based, prospective cohort study of 315,495 individuals. BMC Musculoskelet. Disord. 2014, 15, 217. [CrossRef]

7. Silverwood, V.; Blagojevic-Bucknall, M.; Jinks, C.; Jordan, J.L.; Protheroe, J.; Jordan, K.P. Current evidence on risk factors for knee osteoarthritis in older adults: A systematic review and meta-analysis. Osteoarthritis Cartilage 2015, 23, 507-515. [CrossRef] 
8. Eymard, F.; Parsons, C.; Edwards, M.H.; Petit-Dop, F.; Reginster, J.Y.; Bruyere, O.; Richette, P.; Cooper, C.; Chevalier, X. Diabetes is a risk factor for knee osteoarthritis progression. Osteoarthritis Cartilage 2015, 23, 851-859. [CrossRef]

9. Williams, M.F.; London, D.A.; Husni, E.M.; Navaneethan, S.; Kashyap, S.R. Type 2 diabetes and osteoarthritis: A systematic review and meta-analysis. J. Diabetes Complicat. 2016, 30, 944-950. [CrossRef]

10. van der Esch, M.; Knoop, J.; van der Leeden, M.; Roorda, L.D.; Lems, W.F.; Knol, D.L.; Dekker, J. Clinical phenotypes in patients with knee osteoarthritis: A study in the Amsterdam osteoarthritis cohort. Osteoarthritis Cartilage 2015, 23, 544-549. [CrossRef]

11. Dell'Isola, A.; Allan, R.; Smith, S.L.; Marreiros, S.S.; Steultjens, M. Identification of clinical phenotypes in knee osteoarthritis: A systematic review of the literature. BMC Musculoskelet. Disord. 2016, 17, 425. [CrossRef] [PubMed]

12. Knoop, J.; van der Leeden, M.; Thorstensson, C.A.; Roorda, L.D.; Lems, W.F.; Knol, D.L.; Steultjens, M.P.; Dekker, J. Identification of phenotypes with different clinical outcomes in knee osteoarthritis: Data from the Osteoarthritis Initiative. Arthrit. Care Res. 2011, 63, 1535-1542. [CrossRef] [PubMed]

13. Jaggard, M.K.J.; Boulange, C.L.; Akhbari, P.; Vaghela, U.; Bhattacharya, R.; Williams, H.R.T.; Lindon, J.C.; Gupte, C.M. A systematic review of the small molecule studies of osteoarthritis using nuclear magnetic resonance and mass spectroscopy. Osteoarthritis Cartilage 2018. [CrossRef] [PubMed]

14. Anderson, J.R.; Phelan, M.M.; Clegg, P.D.; Peffers, M.J.; Rubio-Martinez, L.M. Synovial Fluid Metabolites Differentiate between Septic and Nonseptic Joint Pathologies. J. Proteome Res. 2018, 17, 2735-2743. [CrossRef] [PubMed]

15. Carlson, A.K.; Rawle, R.A.; Adams, E.; Greenwood, M.C.; Bothner, B.; June, R.K. Application of global metabolomic profiling of synovial fluid for osteoarthritis biomarkers. Biochem. Biophys. Res. Commun. 2018, 499, 182-188. [CrossRef] [PubMed]

16. Hinata, M.; Imai, S.; Sanaki, T.; Tsuchida, J.; Yoshioka, T.; Higashino, K.; Yamamoto, M.; Imai, M.; Soga, M.; Horita, N.; et al. Sensitization of transient receptor potential vanilloid 4 and increasing its endogenous ligand 5,6-epoxyeicosatrienoic acid in rats with monoiodoacetate-induced osteoarthritis. Pain 2018, 159, 939-947. [CrossRef] [PubMed]

17. Zhang, W.; Sun, G.; Aitken, D.; Likhodii, S.; Liu, M.; Martin, G.; Furey, A.; Randell, E.; Rahman, P.; Jones, G.; et al. Lysophosphatidylcholines to phosphatidylcholines ratio predicts advanced knee osteoarthritis. Rheumatology (Oxford) 2016, 55, 1566-1574. [CrossRef]

18. Jin, W.; Woo, D.C.; Jahng, G.H. In vivo H1 MR spectroscopy using 3 Tesla to investigate the metabolic profiles of joint fluids in different types of knee diseases. J. Appl. Clin. Med. Phys. 2016, 17, 561-572. [CrossRef]

19. Loeser, R.F.; Pathmasiri, W.; Sumner, S.J.; McRitchie, S.; Beavers, D.; Saxena, P.; Nicklas, B.J.; Jordan, J.; Guermazi, A.; Hunter, D.J.; et al. Association of urinary metabolites with radiographic progression of knee osteoarthritis in overweight and obese adults: An exploratory study. Osteoarthritis Cartilage 2016, 24, 1479-1486. [CrossRef]

20. Mickiewicz, B.; Shin, S.Y.; Pozzi, A.; Vogel, H.J.; Clark, A.L. Serum Metabolite Profiles Are Altered by Erlotinib Treatment and the Integrin alpha1-Null Genotype but Not by Post-Traumatic Osteoarthritis. J. Proteome Res. 2016, 15, 815-825. [CrossRef]

21. Hu, T.; Zhang, W.; Fan, Z.; Sun, G.; Likhodi, S.; Randell, E.; Zhai, G. Metabolomics Differential Correlation Network Analysis of Osteoarthritis. Proc. Pac. Symp. 2016, 21, 120-131.

22. Zhang, W.; Sun, G.; Likhodii, S.; Liu, M.; Aref-Eshghi, E.; Harper, P.E.; Martin, G.; Furey, A.; Green, R.; Randell, E.; et al. Metabolomic analysis of human plasma reveals that arginine is depleted in knee osteoarthritis patients. Osteoarthritis Cartilage 2016, 24, 827-834. [CrossRef] [PubMed]

23. Tufts, L.; Shet Vishnudas, K.; Fu, E.; Kurhanewicz, J.; Ries, M.; Alliston, T.; Li, X. Correlating high-resolution magic angle spinning NMR spectroscopy and gene analysis in osteoarthritic cartilage. NMR Biomed. 2015, 28, 523-528. [CrossRef] [PubMed]

24. Zhang, W.; Likhodii, S.; Aref-Eshghi, E.; Zhang, Y.; Harper, P.E.; Randell, E.; Green, R.; Martin, G.; Furey, A.; Sun, G.; et al. Relationship between blood plasma and synovial fluid metabolite concentrations in patients with osteoarthritis. J. Rheumatol. 2015, 42, 859-865. [CrossRef] [PubMed]

25. Zhai, G.; Wang-Sattler, R.; Hart, D.J.; Arden, N.K.; Hakim, A.J.; Illig, T.; Spector, T.D. Serum branched-chain amino acid to histidine ratio: A novel metabolomic biomarker of knee osteoarthritis. Ann. Rheum. Dis. 2010, 69, 1227-1231. [CrossRef] [PubMed] 
26. Davies, M.R.; Ribeiro, L.R.; Downey-Jones, M.; Needham, M.R.; Oakley, C.; Wardale, J. Ligands for retinoic acid receptors are elevated in osteoarthritis and may contribute to pathologic processes in the osteoarthritic joint. Arthritis Rheum. 2009, 60, 1722-1732. [CrossRef]

27. Lamers, R.J.; van Nesselrooij, J.H.; Kraus, V.B.; Jordan, J.M.; Renner, J.B.; Dragomir, A.D.; Luta, G.; van der Greef, J.; DeGroot, J. Identification of an urinary metabolite profile associated with osteoarthritis. Osteoarthritis Cartilage 2005, 13, 762-768. [CrossRef] [PubMed]

28. Basu, S.; Whiteman, M.; Mattey, D.L.; Halliwell, B. Raised levels of F(2)-isoprostanes and prostaglandin F(2alpha) in different rheumatic diseases. Ann. Rheum. Dis. 2001, 60, 627-631. [CrossRef]

29. Wang, X.; Hunter, D.; Xu, J.; Ding, C. Metabolic triggered inflammation in osteoarthritis. Osteoarthritis Cartilage 2015, 23, 22-30. [CrossRef]

30. Kosinska, M.K.; Liebisch, G.; Lochnit, G.; Wilhelm, J.; Klein, H.; Kaesser, U.; Lasczkowski, G.; Rickert, M.; Schmitz, G.; Steinmeyer, J. Sphingolipids in human synovial fluid-A lipidomic study. PLoS ONE 2014, 9 , e91769. [CrossRef]

31. Mickiewicz, B.; Kelly, J.J.; Ludwig, T.E.; Weljie, A.M.; Wiley, J.P.; Schmidt, T.A.; Vogel, H.J. Metabolic analysis of knee synovial fluid as a potential diagnostic approach for osteoarthritis. J. Orthop. Res. 2015, 33, 1631-1638. [CrossRef] [PubMed]

32. Zheng, K.; Shen, N.; Chen, H.; Ni, S.; Zhang, T.; Hu, M.; Wang, J.; Sun, L.; Yang, X. Global and targeted metabolomics of synovial fluid discovers special osteoarthritis metabolites. J. Orthop. Res. 2017, 35, 1973-1981. [CrossRef] [PubMed]

33. Mickiewicz, B.; Heard, B.J.; Chau, J.K.; Chung, M.; Hart, D.A.; Shrive, N.G.; Frank, C.B.; Vogel, H.J. Metabolic profiling of synovial fluid in a unilateral ovine model of anterior cruciate ligament reconstruction of the knee suggests biomarkers for early osteoarthritis. J. Orthop. Res. 2015, 33, 71-77. [CrossRef]

34. Hugle, T.; Kovacs, H.; Heijnen, I.A.; Daikeler, T.; Baisch, U.; Hicks, J.M.; Valderrabano, V. Synovial fluid metabolomics in different forms of arthritis assessed by nuclear magnetic resonance spectroscopy. Clin. Exp. Rheumatol. 2012, 30, 240-245. [PubMed]

35. Anderson, J.R.; Chokesuwattanaskul, S.; Phelan, M.M.; Welting, T.J.M.; Lian, L.Y.; Peffers, M.J.; Wright, H.L. ${ }^{1} \mathrm{H}$ NMR Metabolomics Identifies Underlying Inflammatory Pathology in Osteoarthritis and Rheumatoid Arthritis Synovial Joints. J. Proteome Res. 2018. [CrossRef]

36. Kang, K.Y.; Lee, S.H.; Jung, S.M.; Park, S.H.; Jung, B.H.; Ju, J.H. Downregulation of Tryptophan-related Metabolomic Profile in Rheumatoid Arthritis Synovial Fluid. J. Rheumatol. 2015, 42, 2003-2011. [CrossRef]

37. Kellgren, J.H.; Lawrence, J.S. Radiological assessment of osteo-arthrosis. Ann. Rheum. Dis. 1957, 16, 494-502. [CrossRef] [PubMed]

38. Kim, S.; Hwang, J.; Kim, J.; Ahn, J.K.; Cha, H.S.; Kim, K.H. Metabolite profiles of synovial fluid change with the radiographic severity of knee osteoarthritis. Joint Bone Spine 2017, 84, 605-610. [CrossRef]

39. Cicuttini, F.M.; Wluka, A.E. Osteoarthritis: Is OA a mechanical or systemic disease? Nat. Rev. Rheumatol. 2014, 10, 515-516. [CrossRef] [PubMed]

40. Datta, P.; Zhang, Y.; Parousis, A.; Sharma, A.; Rossomacha, E.; Endisha, H.; Wu, B.; Kacprzak, I.; Mahomed, N.N.; Gandhi, R.; et al. High-fat diet-induced acceleration of osteoarthritis is associated with a distinct and sustained plasma metabolite signature. Sci. Rep. 2017, 7, 8205. [CrossRef] [PubMed]

41. Jiang, H.; Liu, J.; Qin, X.J.; Chen, Y.Y.; Gao, J.R.; Meng, M.; Wang, Y.; Wang, T. Gas chromatography-time of flight/mass spectrometry-based metabonomics of changes in the urinary metabolic profile in osteoarthritic rats. Exp. Ther. Med. 2018, 15, 2777-2785. [CrossRef] [PubMed]

42. Chen, D.; Su, X.; Wang, N.; Li, Y.; Yin, H.; Li, L.; Li, L. Chemical Isotope Labeling LC-MS for Monitoring Disease Progression and Treatment in Animal Models: Plasma Metabolomics Study of Osteoarthritis Rat Model. Sci. Rep. 2017, 7, 40543. [CrossRef] [PubMed]

43. Tootsi, K.; Kals, J.; Zilmer, M.; Paapstel, K.; Ottas, A.; Martson, A. Medium- and long-chain acylcarnitines are associated with osteoarthritis severity and arterial stiffness in end-stage osteoarthritis patients: A case-control study. Int. J. Rheum. Dis. 2018, 21, 1211-1218. [CrossRef] [PubMed]

44. Hawker, G.A.; Croxford, R.; Bierman, A.S.; Harvey, P.J.; Ravi, B.; Stanaitis, I.; Lipscombe, L.L. All-cause mortality and serious cardiovascular events in people with hip and knee osteoarthritis: A population based cohort study. PLoS ONE 2014, 9, e91286. [CrossRef] [PubMed] 
45. Kim, H.S.; Shin, J.S.; Lee, J.; Lee, Y.J.; Kim, M.R.; Bae, Y.H.; Park, K.B.; Lee, E.J.; Kim, J.H.; Ha, I.H. Association between Knee Osteoarthritis, Cardiovascular Risk Factors, and the Framingham Risk Score in South Koreans: A Cross-Sectional Study. PLoS ONE 2016, 11, e0165325. [CrossRef] [PubMed]

46. Williams, A.; Kamper, S.J.; Wiggers, J.H.; O’Brien, K.M.; Lee, H.; Wolfenden, L.; Yoong, S.L.; Robson, E.; McAuley, J.H.; Hartvigsen, J.; et al. Musculoskeletal conditions may increase the risk of chronic disease: A systematic review and meta-analysis of cohort studies. BMC Med. 2018, 16, 167. [CrossRef] [PubMed]

47. Wang, H.; Bai, J.; He, B.; Hu, X.; Liu, D. Osteoarthritis and the risk of cardiovascular disease: A meta-analysis of observational studies. Sci. Rep. 2016, 6, 39672. [CrossRef]

48. Rahman, M.M.; Kopec, J.A.; Anis, A.H.; Cibere, J.; Goldsmith, C.H. Risk of cardiovascular disease in patients with osteoarthritis: A prospective longitudinal study. Arthrit. Care Res. 2013, 65, 1951-1958. [CrossRef]

49. Hall, A.J.; Stubbs, B.; Mamas, M.A.; Myint, P.K.; Smith, T.O. Association between osteoarthritis and cardiovascular disease: Systematic review and meta-analysis. Eur. J. Prev. Cardiol. 2016, 23, 938-946. [CrossRef]

50. Rahman, M.M.; Cibere, J.; Anis, A.H.; Goldsmith, C.H.; Kopec, J.A. Risk of Type 2 Diabetes among Osteoarthritis Patients in a Prospective Longitudinal Study. Int. J. Rheumatol. 2014, 2014, 620920. [CrossRef]

51. Neumann, J.; Hofmann, F.C.; Heilmeier, U.; Ashmeik, W.; Tang, K.; Gersing, A.S.; Schwaiger, B.J.; Nevitt, M.C.; Joseph, G.B.; Lane, N.E.; et al. Type 2 diabetes patients have accelerated cartilage matrix degeneration compared to diabetes free controls: Data from the Osteoarthritis Initiative. Osteoarthritis Cartilage 2018, 26, 751-761. [CrossRef] [PubMed]

52. Jungmann, P.M.; Kraus, M.S.; Alizai, H.; Nardo, L.; Baum, T.; Nevitt, M.C.; McCulloch, C.E.; Joseph, G.B.; Lynch, J.A.; Link, T.M. Association of metabolic risk factors with cartilage degradation assessed by T2 relaxation time at the knee: Data from the osteoarthritis initiative. Arthrit. Care Res. 2013, 65, 1942-1950. [CrossRef] [PubMed]

53. Schett, G.; Kleyer, A.; Perricone, C.; Sahinbegovic, E.; Iagnocco, A.; Zwerina, J.; Lorenzini, R.; Aschenbrenner, F.; Berenbaum, F.; D'Agostino, M.A.; et al. Diabetes is an independent predictor for severe osteoarthritis: Results from a longitudinal cohort study. Diabetes Care 2013, 36, 403-409. [CrossRef] [PubMed]

54. Berenbaum, F. Diabetes-induced osteoarthritis: From a new paradigm to a new phenotype. Ann. Rheum. Dis. 2011, 70, 1354-1356. [CrossRef] [PubMed]

55. Laakso, M.; Kuusisto, J. Insulin resistance and hyperglycaemia in cardiovascular disease development. Nat. Rev. Endocrinol. 2014, 10, 293-302. [CrossRef] [PubMed]

56. Yu, Z.; Zhai, G.; Singmann, P.; He, Y.; Xu, T.; Prehn, C.; Romisch-Margl, W.; Lattka, E.; Gieger, C.; Soranzo, N.; et al. Human serum metabolic profiles are age dependent. Aging Cell 2012, 11, 960-967. [CrossRef] [PubMed]

57. Zhong, F.; Xu, M.; Bruno, R.S.; Ballard, K.D.; Zhu, J. Targeted High Performance Liquid Chromatography Tandem Mass Spectrometry-based Metabolomics differentiates metabolic syndrome from obesity. Exp. Biol. Med. (Maywood) 2017, 242, 773-780. [CrossRef] [PubMed]

58. Rockel, J.S.; Zhang, W.; Shestopaloff, K.; Likhodii, S.; Sun, G.; Furey, A.; Randell, E.; Sundararajan, K.; Gandhi, R.; Zhai, G.; et al. A classification modeling approach for determining metabolite signatures in osteoarthritis. PLoS ONE 2018, 13, e0199618. [CrossRef] [PubMed]

59. Zhang, W.; Likhodii, S.; Zhang, Y.; Aref-Eshghi, E.; Harper, P.E.; Randell, E.; Green, R.; Martin, G.; Furey, A.; Sun, G.; et al. Classification of osteoarthritis phenotypes by metabolomics analysis. BMJ Open 2014, 4, e006286. [CrossRef]

60. Finco, G.; Locci, E.; Mura, P.; Massa, R.; Noto, A.; Musu, M.; Landoni, G.; d'Aloja, E.; De-Giorgio, F.; Scano, P.; et al. Can Urine Metabolomics Be Helpful in Differentiating Neuropathic and Nociceptive Pain? A Proof-of-Concept Study. PLoS ONE 2016, 11, e0150476. [CrossRef]

61. Hadrevi, J.; Bjorklund, M.; Kosek, E.; Hallgren, S.; Antti, H.; Fahlstrom, M.; Hellstrom, F. Systemic differences in serum metabolome: A cross sectional comparison of women with localised and widespread pain and controls. Sci. Rep. 2015, 5, 15925. [CrossRef] [PubMed]

62. Um, S.Y.; Chung, M.W.; Kim, K.B.; Kim, S.H.; Oh, J.S.; Oh, H.Y.; Lee, H.J.; Choi, K.H. Pattern recognition analysis for the prediction of adverse effects by nonsteroidal anti-inflammatory drugs using 1H NMR-based metabolomics in rats. Anal. Chem. 2009, 81, 4734-4741. [CrossRef] [PubMed]

63. Srivastava, N.K.; Yadav, R.; Mukherjee, S.; Sinha, N. Perturbation of muscle metabolism in patients with muscular dystrophy in early or acute phase of disease: In vitro, high resolution NMR spectroscopy based analysis. Clin. Chim. Acta 2018, 478, 171-181. [CrossRef] [PubMed] 
64. Cieslarova, Z.; Lopes, F.S.; do Lago, C.L.; Franca, M.C., Jr.; Colnaghi Simionato, A.V. Capillary electrophoresis tandem mass spectrometry determination of glutamic acid and homocysteine's metabolites: Potential biomarkers of amyotrophic lateral sclerosis. Talanta 2017, 170, 63-68. [CrossRef] [PubMed]

65. Patin, F.; Corcia, P.; Vourc'h, P.; Nadal-Desbarats, L.; Baranek, T.; Goossens, J.F.; Marouillat, S.; Dessein, A.F.; Descat, A.; Madji Hounoum, B.; et al. Omics to Explore Amyotrophic Lateral Sclerosis Evolution: The Central Role of Arginine and Proline Metabolism. Mol. Neurobiol. 2017, 54, 5361-5374. [CrossRef]

66. Files, D.C.; Ilaiwy, A.; Parry, T.L.; Gibbs, K.W.; Liu, C.; Bain, J.R.; Delbono, O.; Muehlbauer, M.J.; Willis, M.S. Lung injury-induced skeletal muscle wasting in aged mice is linked to alterations in long chain fatty acid metabolism. Metabolomics 2016, 12, 134. [CrossRef]

67. Moaddel, R.; Fabbri, E.; Khadeer, M.A.; Carlson, O.D.; Gonzalez-Freire, M.; Zhang, P.; Semba, R.D.; Ferrucci, L. Plasma Biomarkers of Poor Muscle Quality in Older Men and Women from the Baltimore Longitudinal Study of Aging. J. Gerontol. A Biol. Sci. Med. Sci. 2016, 71, 1266-1272. [CrossRef]

68. Wuolikainen, A.; Jonsson, P.; Ahnlund, M.; Antti, H.; Marklund, S.L.; Moritz, T.; Forsgren, L.; Andersen, P.M.; Trupp, M. Multi-platform mass spectrometry analysis of the CSF and plasma metabolomes of rigorously matched amyotrophic lateral sclerosis, Parkinson's disease and control subjects. Mol. Biosyst. 2016, 12, 1287-1298. [CrossRef]

69. Sengupta, M.; Cheema, A.; Kaminski, H.J.; Kusner, L.L.; Muscle Study, G. Serum metabolomic response of myasthenia gravis patients to chronic prednisone treatment. PLoS ONE 2014, 9, e102635. [CrossRef]

70. Cirulli, E.T.; Guo, L.; Leon Swisher, C.; Shah, N.; Huang, L.; Napier, L.A.; Kirkness, E.F.; Spector, T.D.; Caskey, C.T.; Thorens, B.; et al. Profound Perturbation of the Metabolome in Obesity Is Associated with Health Risk. Cell Metab. 2018. [CrossRef]

71. Libert, D.M.; Nowacki, A.S.; Natowicz, M.R. Metabolomic analysis of obesity, metabolic syndrome, and type 2 diabetes: Amino acid and acylcarnitine levels change along a spectrum of metabolic wellness. PeerJ 2018, 6, e5410. [CrossRef] [PubMed]

72. Moore, S.C.; Playdon, M.C.; Sampson, J.N.; Hoover, R.N.; Trabert, B.; Matthews, C.E.; Ziegler, R.G. A Metabolomics Analysis of Body Mass Index and Postmenopausal Breast Cancer Risk. J. Natl. Cancer Inst. 2018, 110, 588-597. [CrossRef] [PubMed]

73. Muniandy, M.; Velagapudi, V.; Hakkarainen, A.; Lundbom, J.; Lundbom, N.; Rissanen, A.; Kaprio, J.; Pietilainen, K.H.; Ollikainen, M. Plasma metabolites reveal distinct profiles associating with different metabolic risk factors in monozygotic twin pairs. Int. J. Obes. (Lond.) 2018. [CrossRef] [PubMed]

74. Baek, S.H.; Kim, M.; Kim, M.; Kang, M.; Yoo, H.J.; Lee, N.H.; Kim, Y.H.; Song, M.; Lee, J.H. Metabolites distinguishing visceral fat obesity and atherogenic traits in individuals with overweight. Obesity (Silver Spring) 2017, 25, 323-331. [CrossRef] [PubMed]

75. Carayol, M.; Leitzmann, M.F.; Ferrari, P.; Zamora-Ros, R.; Achaintre, D.; Stepien, M.; Schmidt, J.A.; Travis, R.C.; Overvad, K.; Tjonneland, A.; et al. Blood Metabolic Signatures of Body Mass Index: A Targeted Metabolomics Study in the EPIC Cohort. J. Proteome Res. 2017, 16, 3137-3146. [CrossRef] [PubMed]

76. Okekunle, A.P.; Li, Y.; Liu, L.; Du, S.; Wu, X.; Chen, Y.; Li, Y.; Qi, J.; Sun, C.; Feng, R. Abnormal circulating amino acid profiles in multiple metabolic disorders. Diabetes Res. Clin. Pract. 2017, 132, 45-58. [CrossRef] [PubMed]

77. Bogl, L.H.; Kaye, S.M.; Ramo, J.T.; Kangas, A.J.; Soininen, P.; Hakkarainen, A.; Lundbom, J.; Lundbom, N.; Ortega-Alonso, A.; Rissanen, A.; et al. Abdominal obesity and circulating metabolites: A twin study approach. Metabolism 2016, 65, 111-121. [CrossRef]

78. Dugas, L.R.; Chorell, E.; Plange-Rhule, J.; Lambert, E.V.; Cao, G.; Cooper, R.S.; Layden, B.T.; Scholten, D.; Olsson, T.; Luke, A.; et al. Obesity-related metabolite profiles of black women spanning the epidemiologic transition. Metabolomics 2016, 12, 45. [CrossRef]

79. Gao, X.; Zhang, W.; Wang, Y.; Pedram, P.; Cahill, F.; Zhai, G.; Randell, E.; Gulliver, W.; Sun, G. Serum metabolic biomarkers distinguish metabolically healthy peripherally obese from unhealthy centrally obese individuals. Nutr. Metab. (Lond.) 2016, 13, 33. [CrossRef]

80. Ho, J.E.; Larson, M.G.; Ghorbani, A.; Cheng, S.; Chen, M.H.; Keyes, M.; Rhee, E.P.; Clish, C.B.; Vasan, R.S.; Gerszten, R.E.; et al. Metabolomic Profiles of Body Mass Index in the Framingham Heart Study Reveal Distinct Cardiometabolic Phenotypes. PLoS ONE 2016, 11, e0148361. [CrossRef] 
81. Tulipani, S.; Palau-Rodriguez, M.; Minarro Alonso, A.; Cardona, F.; Marco-Ramell, A.; Zonja, B.; Lopez de Alda, M.; Munoz-Garach, A.; Sanchez-Pla, A.; Tinahones, F.J.; et al. Biomarkers of Morbid Obesity and Prediabetes by Metabolomic Profiling of Human Discordant Phenotypes. Clin. Chim. Acta 2016, 463, 53-61. [CrossRef] [PubMed]

82. Zhao, H.; Shen, J.; Djukovic, D.; Daniel-MacDougall, C.; Gu, H.; Wu, X.; Chow, W.H. Metabolomics-identified metabolites associated with body mass index and prospective weight gain among Mexican American women. Obes. Sci. Pract. 2016, 2, 309-317. [CrossRef] [PubMed]

83. Boulet, M.M.; Chevrier, G.; Grenier-Larouche, T.; Pelletier, M.; Nadeau, M.; Scarpa, J.; Prehn, C.; Marette, A.; Adamski, J.; Tchernof, A. Alterations of plasma metabolite profiles related to adipose tissue distribution and cardiometabolic risk. Am. J. Physiol. Endocrinol. Metab. 2015, 309, E736-E746. [CrossRef] [PubMed]

84. Chen, H.H.; Tseng, Y.J.; Wang, S.Y.; Tsai, Y.S.; Chang, C.S.; Kuo, T.C.; Yao, W.J.; Shieh, C.C.; Wu, C.H.; Kuo, P.H. The metabolome profiling and pathway analysis in metabolic healthy and abnormal obesity. Int. J. Obes. (Lond.) 2015, 39, 1241-1248. [CrossRef] [PubMed]

85. Gralka, E.; Luchinat, C.; Tenori, L.; Ernst, B.; Thurnheer, M.; Schultes, B. Metabolomic fingerprint of severe obesity is dynamically affected by bariatric surgery in a procedure-dependent manner. Am. J. Clin. Nutr. 2015, 102, 1313-1322. [CrossRef] [PubMed]

86. Floegel, A.; Wientzek, A.; Bachlechner, U.; Jacobs, S.; Drogan, D.; Prehn, C.; Adamski, J.; Krumsiek, J.; Schulze, M.B.; Pischon, T.; et al. Linking diet, physical activity, cardiorespiratory fitness and obesity to serum metabolite networks: Findings from a population-based study. Int. J. Obes. (Lond.) 2014, 38, 1388-1396. [CrossRef] [PubMed]

87. Moore, S.C.; Matthews, C.E.; Sampson, J.N.; Stolzenberg-Solomon, R.Z.; Zheng, W.; Cai, Q.; Tan, Y.T.; Chow, W.H.; Ji, B.T.; Liu, D.K.; et al. Human metabolic correlates of body mass index. Metabolomics 2014, 10, 259-269. [CrossRef] [PubMed]

88. Martin, F.P.; Montoliu, I.; Collino, S.; Scherer, M.; Guy, P.; Tavazzi, I.; Thorimbert, A.; Moco, S.; Rothney, M.P.; Ergun, D.L.; et al. Topographical body fat distribution links to amino acid and lipid metabolism in healthy obese women [corrected]. PLoS ONE 2013, 8, e73445. [CrossRef]

89. Batch, B.C.; Shah, S.H.; Newgard, C.B.; Turer, C.B.; Haynes, C.; Bain, J.R.; Muehlbauer, M.; Patel, M.J.; Stevens, R.D.; Appel, L.J.; et al. Branched chain amino acids are novel biomarkers for discrimination of metabolic wellness. Metabolism 2013, 62, 961-969. [CrossRef]

90. Ali-Sisto, T.; Tolmunen, T.; Viinamaki, H.; Mantyselka, P.; Valkonen-Korhonen, M.; Koivumaa-Honkanen, H.; Honkalampi, K.; Ruusunen, A.; Nandania, J.; Velagapudi, V.; et al. Global arginine bioavailability ratio is decreased in patients with major depressive disorder. J. Affect. Disord. 2018, 229, 145-151. [CrossRef]

91. Kawamura, N.; Shinoda, K.; Sato, H.; Sasaki, K.; Suzuki, M.; Yamaki, K.; Fujimori, T.; Yamamoto, H.; Osei-Hyiaman, D.; Ohashi, Y. Plasma metabolome analysis of patients with major depressive disorder. Psychiatry Clin. Neurosci. 2018, 72, 349-361. [CrossRef] [PubMed]

92. Moaddel, R.; Shardell, M.; Khadeer, M.; Lovett, J.; Kadriu, B.; Ravichandran, S.; Morris, P.J.; Yuan, P.; Thomas, C.J.; Gould, T.D.; et al. Plasma metabolomic profiling of a ketamine and placebo crossover trial of major depressive disorder and healthy control subjects. Psychopharmacology (Berl.) 2018, 235, 3017-3030. [CrossRef] [PubMed]

93. Zheng, H.; Zheng, P.; Zhao, L.; Jia, J.; Tang, S.; Xu, P.; Xie, P.; Gao, H. Predictive diagnosis of major depression using NMR-based metabolomics and least-squares support vector machine. Clin. Chim. Acta 2017, 464, 223-227. [CrossRef] [PubMed]

94. Ali-Sisto, T.; Tolmunen, T.; Toffol, E.; Viinamaki, H.; Mantyselka, P.; Valkonen-Korhonen, M.; Honkalampi, K.; Ruusunen, A.; Velagapudi, V.; Lehto, S.M. Purine metabolism is dysregulated in patients with major depressive disorder. Psychoneuroendocrinology 2016, 70, 25-32. [CrossRef] [PubMed]

95. Liu, Y.; Yieh, L.; Yang, T.; Drinkenburg, W.; Peeters, P.; Steckler, T.; Narayan, V.A.; Wittenberg, G.; Ye, J. Metabolomic biosignature differentiates melancholic depressive patients from healthy controls. BMC Genom. 2016, 17, 669. [CrossRef] [PubMed]

96. Rotroff, D.M.; Corum, D.G.; Motsinger-Reif, A.; Fiehn, O.; Bottrel, N.; Drevets, W.C.; Singh, J.; Salvadore, G.; Kaddurah-Daouk, R. Metabolomic signatures of drug response phenotypes for ketamine and esketamine in subjects with refractory major depressive disorder: New mechanistic insights for rapid acting antidepressants. Transl. Psychiatry 2016, 6, e894. [CrossRef] [PubMed] 
97. Setoyama, D.; Kato, T.A.; Hashimoto, R.; Kunugi, H.; Hattori, K.; Hayakawa, K.; Sato-Kasai, M.; Shimokawa, N.; Kaneko, S.; Yoshida, S.; et al. Plasma Metabolites Predict Severity of Depression and Suicidal Ideation in Psychiatric Patients-A Multicenter Pilot Analysis. PLoS ONE 2016, 11, e0165267. [CrossRef] [PubMed]

98. Zheng, P.; Chen, J.J.; Zhou, C.J.; Zeng, L.; Li, K.W.; Sun, L.; Liu, M.L.; Zhu, D.; Liang, Z.H.; Xie, P. Identification of sex-specific urinary biomarkers for major depressive disorder by combined application of NMR- and GC-MS-based metabonomics. Transl. Psychiatry 2016, 6, e955. [CrossRef]

99. Woo, H.I.; Chun, M.R.; Yang, J.S.; Lim, S.W.; Kim, M.J.; Kim, S.W.; Myung, W.J.; Kim, D.K.; Lee, S.Y. Plasma amino acid profiling in major depressive disorder treated with selective serotonin reuptake inhibitors. CNS Neurosci. Ther. 2015, 21, 417-424. [CrossRef]

100. Zheng, P.; Gao, H.C.; Li, Q.; Shao, W.H.; Zhang, M.L.; Cheng, K.; Yang, D.Y.; Fan, S.H.; Chen, L.; Fang, L.; et al. Plasma metabonomics as a novel diagnostic approach for major depressive disorder. J. Proteome Res. 2012, 11, 1741-1748. [CrossRef]

101. Paige, L.A.; Mitchell, M.W.; Krishnan, K.R.; Kaddurah-Daouk, R.; Steffens, D.C. A preliminary metabolomic analysis of older adults with and without depression. Int. J. Geriatr. Psychiatry 2007, 22, 418-423. [CrossRef] [PubMed]

102. Thakur, M.; Dickenson, A.H.; Baron, R. Osteoarthritis pain: Nociceptive or neuropathic? Nat. Rev. Rheumatol. 2014, 10, 374-380. [CrossRef]

103. La Porta, C.; Bura, S.A.; Negrete, R.; Maldonado, R. Involvement of the endocannabinoid system in osteoarthritis pain. Eur. J. Neurosci. 2014, 39, 485-500. [CrossRef] [PubMed]

104. Richardson, D.; Pearson, R.G.; Kurian, N.; Latif, M.L.; Garle, M.J.; Barrett, D.A.; Kendall, D.A.; Scammell, B.E.; Reeve, A.J.; Chapman, V. Characterisation of the cannabinoid receptor system in synovial tissue and fluid in patients with osteoarthritis and rheumatoid arthritis. Arthritis Res. Ther. 2008, 10, R43. [CrossRef] [PubMed]

105. Muccioli, G.G. Endocannabinoid biosynthesis and inactivation, from simple to complex. Drug Discov. Today 2010, 15, 474-483. [CrossRef] [PubMed]

106. Oiestad, B.E.; Juhl, C.B.; Eitzen, I.; Thorlund, J.B. Knee extensor muscle weakness is a risk factor for development of knee osteoarthritis. A systematic review and meta-analysis. Osteoarthritis Cartilage 2015, 23, 171-177. [CrossRef] [PubMed]

107. Culvenor, A.G.; Ruhdorfer, A.; Juhl, C.; Eckstein, F.; Oiestad, B.E. Knee Extensor Strength and Risk of Structural, Symptomatic, and Functional Decline in Knee Osteoarthritis: A Systematic Review and Meta-Analysis. Arthrit. Care Res. 2017, 69, 649-658. [CrossRef] [PubMed]

108. Kumar, A.; Ghosh, D.; Singh, R.L. Amyotrophic Lateral Sclerosis and Metabolomics: Clinical Implication and Therapeutic Approach. J. Biomark. 2013, 2013, 538765. [CrossRef] [PubMed]

109. Blasco, H.; Patin, F.; Madji Hounoum, B.; Gordon, P.H.; Vourc'h, P.; Andres, C.R.; Corcia, P. Metabolomics in amyotrophic lateral sclerosis: How far can it take us? Eur. J. Neurol. 2016, 23, 447-454. [CrossRef]

110. Edwards, R.R.; Cahalan, C.; Mensing, G.; Smith, M.; Haythornthwaite, J.A. Pain, catastrophizing, and depression in the rheumatic diseases. Nat. Rev. Rheumatol. 2011, 7, 216-224. [CrossRef]

111. Miyamoto, K.; Ohkawara, B.; Ito, M.; Masuda, A.; Hirakawa, A.; Sakai, T.; Hiraiwa, H.; Hamada, T.; Ishiguro, N.; Ohno, K. Fluoxetine ameliorates cartilage degradation in osteoarthritis by inhibiting Wnt/beta-catenin signaling. PLoS ONE 2017, 12, e0184388. [CrossRef] [PubMed]

112. Murakami, M.; Nakatani, Y.; Atsumi, G.I.; Inoue, K.; Kudo, I. Regulatory Functions of Phospholipase A2. Crit. Rev. Immunol. 2017, 37, 121-179. [CrossRef] [PubMed]

113. Jamal, O.S.; Conaghan, P.G.; Cunningham, A.M.; Brooks, P.M.; Munro, V.F.; Scott, K.F. Increased expression of human type IIa secretory phospholipase A2 antigen in arthritic synovium. Ann. Rheum. Dis. 1998, 57, 550-558. [CrossRef] [PubMed]

114. Pruzanski, W.; Bogoch, E.; Katz, A.; Wloch, M.; Stefanski, E.; Grouix, B.; Sakotic, G.; Vadas, P. Induction of release of secretory nonpancreatic phospholipase A2 from human articular chondrocytes. J. Rheumatol. 1995, 22, 2114-2119. [PubMed]

115. Tokumura, A.; Harada, K.; Fukuzawa, K.; Tsukatani, H. Involvement of lysophospholipase D in the production of lysophosphatidic acid in rat plasma. Biochim. Biophys. Acta 1986, 875, 31-38. [PubMed]

116. Tokumura, A.; Majima, E.; Kariya, Y.; Tominaga, K.; Kogure, K.; Yasuda, K.; Fukuzawa, K. Identification of human plasma lysophospholipase D, a lysophosphatidic acid-producing enzyme, as autotaxin, a multifunctional phosphodiesterase. J. Biol. Chem. 2002, 277, 39436-39442. [CrossRef] [PubMed] 
117. Inoue, M.; Rashid, M.H.; Fujita, R.; Contos, J.J.; Chun, J.; Ueda, H. Initiation of neuropathic pain requires lysophosphatidic acid receptor signaling. Nat. Med. 2004, 10, 712-718. [CrossRef]

118. Uchida, H.; Nagai, J.; Ueda, H. Lysophosphatidic acid and its receptors LPA1 and LPA3 mediate paclitaxel-induced neuropathic pain in mice. Mol. Pain 2014, 10, 71. [CrossRef]

119. Inoue, M.; Xie, W.; Matsushita, Y.; Chun, J.; Aoki, J.; Ueda, H. Lysophosphatidylcholine induces neuropathic pain through an action of autotaxin to generate lysophosphatidic acid. Neuroscience 2008, 152, 296-298. [CrossRef]

120. Gustin, C.; Van Steenbrugge, M.; Raes, M. LPA modulates monocyte migration directly and via LPA-stimulated endothelial cells. Am. J. Physiol. Cell Physiol. 2008, 295, C905-C914. [CrossRef]

121. Zhou, D.; Luini, W.; Bernasconi, S.; Diomede, L.; Salmona, M.; Mantovani, A.; Sozzani, S. Phosphatidic acid and lysophosphatidic acid induce haptotactic migration of human monocytes. J. Biol. Chem. 1995, 270, 25549-25556. [CrossRef] [PubMed]

122. Zhao, J.; Wei, J.; Weathington, N.; Jacko, A.M.; Huang, H.; Tsung, A.; Zhao, Y. Lysophosphatidic acid receptor 1 antagonist ki16425 blunts abdominal and systemic inflammation in a mouse model of peritoneal sepsis. Transl. Res. 2015, 166, 80-88. [CrossRef] [PubMed]

123. Goldshmit, Y.; Matteo, R.; Sztal, T.; Ellett, F.; Frisca, F.; Moreno, K.; Crombie, D.; Lieschke, G.J.; Currie, P.D.; Sabbadini, R.A.; et al. Blockage of lysophosphatidic acid signaling improves spinal cord injury outcomes. Am. J. Pathol. 2012, 181, 978-992. [CrossRef] [PubMed]

124. Mabey, T.; Taleongpong, P.; Udomsinprasert, W.; Jirathanathornnukul, N.; Honsawek, S. Plasma and synovial fluid autotaxin correlate with severity in knee osteoarthritis. Clin. Chim. Acta 2015, 444, 72-77. [CrossRef] [PubMed]

125. McDougall, J.J.; Albacete, S.; Schuelert, N.; Mitchell, P.G.; Lin, C.; Oskins, J.L.; Bui, H.H.; Chambers, M.G. Lysophosphatidic acid provides a missing link between osteoarthritis and joint neuropathic pain. Osteoarthritis Cartilage 2017, 25, 926-934. [CrossRef] [PubMed]

126. Thirunavukkarasu, K.; Swearingen, C.A.; Oskins, J.L.; Lin, C.; Bui, H.H.; Jones, S.B.; Pfeifer, L.A.; Norman, B.H.; Mitchell, P.G.; Chambers, M.G. Identification and pharmacological characterization of a novel inhibitor of autotaxin in rodent models of joint pain. Osteoarthritis Cartilage 2017, 25, 935-942. [CrossRef] [PubMed]

127. Vuolteenaho, K.; Koskinen, A.; Moilanen, T.; Moilanen, E. Leptin levels are increased and its negative regulators, SOCS-3 and sOb-R are decreased in obese patients with osteoarthritis: A link between obesity and osteoarthritis. Ann. Rheum. Dis. 2012, 71, 1912-1913. [CrossRef]

128. Stannus, O.P.; Cao, Y.; Antony, B.; Blizzard, L.; Cicuttini, F.; Jones, G.; Ding, C. Cross-sectional and longitudinal associations between circulating leptin and knee cartilage thickness in older adults. Ann. Rheum. Dis. 2015, 74, 82-88. [CrossRef]

129. Zhang, P.; Zhong, Z.H.; Yu, H.T.; Liu, B. Significance of increased leptin expression in osteoarthritis patients. PLoS ONE 2015, 10, e0123224. [CrossRef]

130. Beekhuizen, M.; Gierman, L.M.; van Spil, W.E.; Van Osch, G.J.; Huizinga, T.W.; Saris, D.B.; Creemers, L.B.; Zuurmond, A.M. An explorative study comparing levels of soluble mediators in control and osteoarthritic synovial fluid. Osteoarthritis Cartilage 2013, 21, 918-922. [CrossRef]

131. Rockel, J.S.; Kapoor, M. Autophagy: Controlling cell fate in rheumatic diseases. Nat. Rev. Rheumatol. 2017, 13, 193. [CrossRef] [PubMed]

132. Neishabouri, S.H.; Hutson, S.M.; Davoodi, J. Chronic activation of mTOR complex 1 by branched chain amino acids and organ hypertrophy. Amino Acids 2015, 47, 1167-1182. [CrossRef] [PubMed]

133. Zhenyukh, O.; Civantos, E.; Ruiz-Ortega, M.; Sanchez, M.S.; Vazquez, C.; Peiro, C.; Egido, J.; Mas, S. High concentration of branched-chain amino acids promotes oxidative stress, inflammation and migration of human peripheral blood mononuclear cells via mTORC1 activation. Free Radic. Biol. Med. 2017, 104, $165-177$. [CrossRef] [PubMed]

134. Kapoor, M.; Martel-Pelletier, J.; Lajeunesse, D.; Pelletier, J.P.; Fahmi, H. Role of proinflammatory cytokines in the pathophysiology of osteoarthritis. Nat. Rev. Rheumatol. 2011, 7, 33-42. [CrossRef] [PubMed]

135. Zhang, Y.; Vasheghani, F.; Li, Y.H.; Blati, M.; Simeone, K.; Fahmi, H.; Lussier, B.; Roughley, P.; Lagares, D.; Pelletier, J.P.; et al. Cartilage-specific deletion of mTOR upregulates autophagy and protects mice from osteoarthritis. Ann. Rheum. Dis. 2015, 74, 1432-1440. [CrossRef] [PubMed] 
136. Takayama, K.; Kawakami, Y.; Kobayashi, M.; Greco, N.; Cummins, J.H.; Matsushita, T.; Kuroda, R.; Kurosaka, M.; Fu, F.H.; Huard, J. Local intra-articular injection of rapamycin delays articular cartilage degeneration in a murine model of osteoarthritis. Arthritis Res. Ther. 2014, 16, 482. [CrossRef] [PubMed]

137. Lynch, C.J.; Adams, S.H. Branched-chain amino acids in metabolic signalling and insulin resistance. Nat. Rev. Endocrinol. 2014, 10, 723-736. [CrossRef]

138. Abramson, S.B.; Amin, A.R.; Clancy, R.M.; Attur, M. The role of nitric oxide in tissue destruction. Best Pract. Res. Clin. Rheumatol. 2001, 15, 831-845. [CrossRef]

139. Shearer, J.D.; Richards, J.R.; Mills, C.D.; Caldwell, M.D. Differential regulation of macrophage arginine metabolism: A proposed role in wound healing. Am. J. Physiol. 1997, 272, E181-E190. [CrossRef]

140. Wehling-Henricks, M.; Jordan, M.C.; Gotoh, T.; Grody, W.W.; Roos, K.P.; Tidball, J.G. Arginine metabolism by macrophages promotes cardiac and muscle fibrosis in mdx muscular dystrophy. PLoS ONE 2010, 5, e10763. [CrossRef]

141. Moore, J.P.; Vinh, A.; Tuck, K.L.; Sakkal, S.; Krishnan, S.M.; Chan, C.T.; Lieu, M.; Samuel, C.S.; Diep, H.; Kemp-Harper, B.K.; et al. M2 macrophage accumulation in the aortic wall during angiotensin II infusion in mice is associated with fibrosis, elastin loss, and elevated blood pressure. Am. J. Physiol. Heart Circ. Physiol. 2015, 309, H906-H917. [CrossRef]

142. Wang, Y.; Wehling-Henricks, M.; Samengo, G.; Tidball, J.G. Increases of M2a macrophages and fibrosis in aging muscle are influenced by bone marrow aging and negatively regulated by muscle-derived nitric oxide. Aging Cell 2015, 14, 678-688. [CrossRef] [PubMed]

143. Pesce, J.T.; Ramalingam, T.R.; Mentink-Kane, M.M.; Wilson, M.S.; El Kasmi, K.C.; Smith, A.M.; Thompson, R.W.; Cheever, A.W.; Murray, P.J.; Wynn, T.A. Arginase-1-expressing macrophages suppress Th2 cytokine-driven inflammation and fibrosis. PLoS Pathog. 2009, 5, e1000371. [CrossRef] [PubMed]

144. Barron, L.; Smith, A.M.; El Kasmi, K.C.; Qualls, J.E.; Huang, X.; Cheever, A.; Borthwick, L.A.; Wilson, M.S.; Murray, P.J.; Wynn, T.A. Role of arginase 1 from myeloid cells in th2-dominated lung inflammation. PLoS ONE 2013, 8, e61961. [CrossRef] [PubMed]

145. Yamada, H.; Nakashima, Y.; Okazaki, K.; Mawatari, T.; Fukushi, J.; Oyamada, A.; Fujimura, K.; Iwamoto, Y.; Yoshikai, Y. Preferential accumulation of activated Th1 cells not only in rheumatoid arthritis but also in osteoarthritis joints. J. Rheumatol. 2011, 38, 1569-1575. [CrossRef] [PubMed]

146. Dolganiuc, A.; Stavaru, C.; Anghel, M.; Georgescu, E.; Chichos, B.; Olinescu, A. Shift toward T lymphocytes with Th1 and Tc1 cytokine-secterion profile in the joints of patients with osteoarthritis. Roum. Arch. Microbiol. Immunol. 1999, 58, 249-258. [PubMed]

147. Ishii, H.; Tanaka, H.; Katoh, K.; Nakamura, H.; Nagashima, M.; Yoshino, S. Characterization of infiltrating T cells and Th1/Th2-type cytokines in the synovium of patients with osteoarthritis. Osteoarthritis Cartilage 2002, 10, 277-281. [CrossRef]

148. Vuolteenaho, K.; Moilanen, T.; Knowles, R.G.; Moilanen, E. The role of nitric oxide in osteoarthritis. Scand. J. Rheumatol. 2007, 36, 247-258. [CrossRef]

149. Clements, K.M.; Price, J.S.; Chambers, M.G.; Visco, D.M.; Poole, A.R.; Mason, R.M. Gene deletion of either interleukin-1beta, interleukin-1beta-converting enzyme, inducible nitric oxide synthase, or stromelysin 1 accelerates the development of knee osteoarthritis in mice after surgical transection of the medial collateral ligament and partial medial meniscectomy. Arthritis Rheum. 2003, 48, 3452-3463.

(C) 2018 by the authors. Licensee MDPI, Basel, Switzerland. This article is an open access article distributed under the terms and conditions of the Creative Commons Attribution (CC BY) license (http://creativecommons.org/licenses/by/4.0/). 